\title{
Reflections on the Evolution of the State of the Art
}

\author{
Daniel Levine \\ Department of Political Science, University of Michigan, Ann Arbor, MI 48109, USA; dhldylan@umich.edu
}

Received: 20 December 2018; Accepted: 2 February 2019; Published: 6 February 2019

\begin{abstract}
Reflections on the evolution of the state of the art in the study of religion, society, and politics in Latin America over the last five decades begin with a critical assessment of the conventional wisdom of fifty years ago, as conveyed in texts and in graduate education. Stress was placed on modernization and secularization (with religion depicted as static and destined to decline) on consensus as a foundation for social life, and on drawing clear lines between religion and politics. These concepts were of little use when confronted in the late 1960s with a reality of continuous change, conflict, and efforts from left and right to assert a public role for religion. Working concepts of religion and politics had to be broadened well beyond church and state. Conceptual space had to be found for religious pluralism as the emergence of Pentecostal and evangelical churches was putting an end to centuries of Catholic monopoly: Latin America was becoming religiously plural. The state of the art is now much improved. Current and future research could usefully focus attention on issues like sexuality, gender, and identity, spirituality and encounters with charismatic power, and the new realities of religion and violence. Mid-range theories that give prominence to change and to the relation among social levels, and mixed methodologies that highlight meaning and significance will be central to any future state of the art that can make sense of a reality marked by continuing waves of creative change.
\end{abstract}

Keywords: Latin America; religion; politics; methodology; theory

These are personal reflections on my experience with the state of the art of the study of religion, society, and politics in Latin America over more than 50 years of research and publication. I am a scholar of North American origins and training, but also deeply affected by European and Latin American scholarship. I happily acknowledge my debt to Latin American colleagues and students, many of whom are cited in the Bibliography. I discuss how I had to unlearn what I had been taught in graduate school in order to see and understand what I encountered once on the ground. I then ask if we are better now than we were five decades ago, better prepared to grasp and explain a reality marked by successive waves of change. A third section suggests elements for an agenda for future work. I close with brief reflections on theory and method.

\section{Unlearning in Order to Learn}

I first set foot in Latin America over 50 years ago. I came directly from graduate education (London School of Economics and Yale University), where I had been schooled in the conventional wisdom of the time. Central concepts included modernization and secularization which were presumed to evolve together in a progressive and irreversible process of "development." From this perspective, religion was a fossil, static and destined in the long run to disappear in the face of advancing science and education, and in the short run to lose members and public position. It was the perfect representative of "tradition" as opposed to "modernity."

Once I hit the ground, I encountered a very different reality. These were times of great change in religion and in the churches. The Catholic Church was just beginning to grapple with the impacts of the Second Vatican Council (1962-65), the regional bishops' meetings at Medellin Colombia (1968), 
the first stirrings of the theology of liberation, and the emergence of activist social movements of both the Catholic left and right in various countries. ${ }^{1}$ It was also possible to see the beginnings of the surge of evangelical and Pentecostal churches, soon to become a major wave that would transform religious life and practice throughout the region, and change forever the presence of religion in the public sphere (Cox 1995; Oro and Saman 2000; Chesnut 2003, 1997; Parker 2005; Steigenga 2001; Steigenga and Cleary 2007; Stoll 1990).

I still have a photograph (Figure 1) I took in Guatemala in 1968, in the indigenous village of Solalá, perched above the shores of Lake Atitlán. The photo shows a preacher, speaking in the midst of the weekly market. The market was in full swing, with people buying, selling, and visiting one another. In the midst of all this activity, the preacher was standing, in front of a large hand-painted canvas that depicted heaven and hell, the path of the just and of the damned, all illustrated with vivid images and biblical citations. I kept the photo for many years as a lovely and interesting image, but without grasping its full significance. This preacher was a real precursor, a sign of what was to come. Now we meet his successors in any public square, train or bus station or simply on the corner or sidewalk, preaching with a megaphone, handing out pamphlets, inviting passersby to meetings, building churches and communities. The example of the Guatemalan preacher, the precursor, underscores a central point in any effort to evaluate the state of the art in the study of religion society and politics. The point is that reality comes first: theory follows, often with a notable time lag. Reality changes continually; theory has to catch up. What this means for students of reality is that we must always be open to being surprised, ready to accept things that don't fit into our preconceived schemes. We need to work with the new realities that press themselves on us, and then try to make sense of them, building a new and consistent theory.

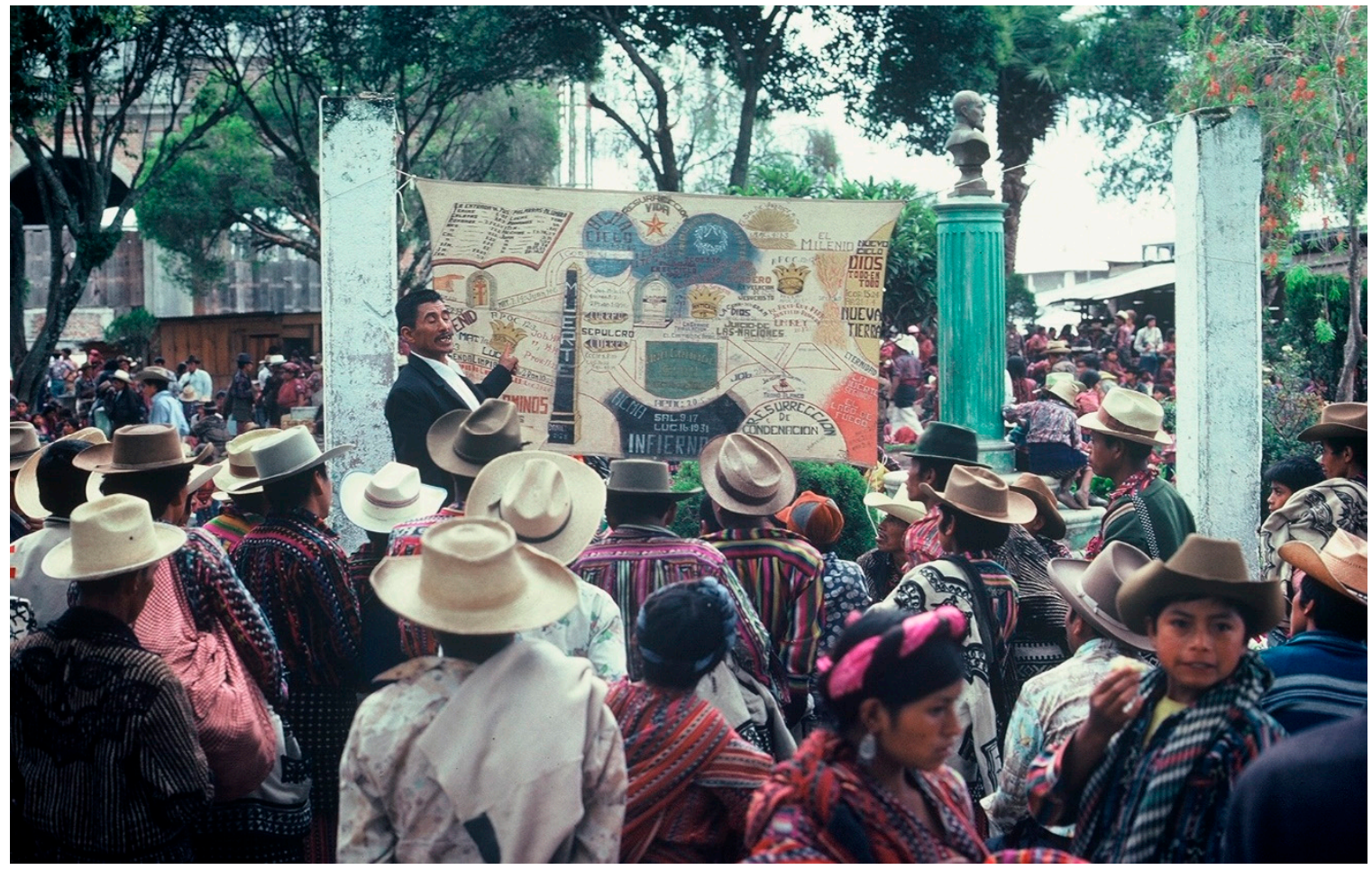

Figure 1. Solalá, Guatrmala, 1968, photo by author. 
It is now more than obvious that, instead of fading away, in much of the world religion is now vigorous, dynamic, and creative. Far from being static, religions everywhere change continually in form and expression. Far from limiting themselves to the personal and private, they actively claim a role in public life. Moreover, in Latin America it is no longer possible to speak of "the church". Now there are many churches and religiously linked movements of all kinds competing for members, resources, and a visible and legitimate place in public life. It has been commonplace to talk about this in terms of a "resurgence of religion" but it would be more accurate to see it as a reordering or reorganization of long-standing relationships. Religion has always been present: what has changed are the voices, the actors, the leaders and followers, the social location of movements and of conflicts, the forms and speed of communication, the issues and forms of expression that move people and which they see as proper and legitimate.

I am a political scientist by training, and in my discipline it was common in those early years to stress the need for clear lines between "religion" and "politics" (identified for all practical purposes with "church" and "state"). The concept of "politicization of religion" was in common use, as if there existed a thermometer the could measure the level of such politicization: high was taken to be bad, low good. To be sure, seeing the process from another angle, it would have been possible and useful to search not for lines of separation or levels of politicization (if it were even possible to find a measure) but rather for syntheses, asking who was active, with what goals, what resources, which allies, where and under what specific conditions, and so forth. These are good questions, but in my case they came later, under the impact of experience that differed radically from what my education and training had led me to expect.

A few years after my initial encounter with Latin American reality, I organized and carried out a comparative study of religion, society, and politics based on field work in Colombia and Venezuela. I interviewed 60 Catholic bishops and carried out extensive field studies in different regions and levels in the two countries. The idea was to compare contrasting cases of the Catholic Church facing the modern world and reacting to change. The working assumption was that the sources of change were external to religious life and to the churches as institutions. Once again, reality had surprises in store for me: I encountered a Catholic Church in ferment, with intense internal debates. Change and conflict were not impelled only by reaction to external pressures, but also and notably as a result of internal transformations, debates about ideas and conflicts between groups within the church, above all concerning the proper social and political role of religion, of formal institutions and more generally of people of faith.

Just a few years earlier in Colombia, Camilo Torres, the guerrilla priest, had been killed in combat with the army and buried in an unmarked grave. Torres had famously written of revolution as a "christian imperative" and saw bearing arms as an act of charity in the pursuit of justice (Levine 2011) This was also the time of the Movement of Christians for Socialism in Chile, the Movement of Third World Priests in Argentina, along similar groups in many countries, not to mention those on the right. Also around this time the first major works of liberation theology began to appear. Among other things, liberation theology flat out rejects the idea of separation of religion from politics. Neutrality was seen as an illusion: a convenient excuse for continuing to affirm the established order. Far from searching for ways out of politics, at issue were new efforts entering the political sphere, no longer in terms of elite influences or partisan politics, but rather in pursuit of basic changes in the structure of power that kept injustice in place (Gutierrez 1971).

All this affected me like an alarm clock. It opened my eyes and made me see things from a wholly different perspective. It was time to wake up and to rethink. My formal preparation had left me innocent of the change under way and lacking theoretical and methodological tools to make sense of the reality I was encountering every day. I had to rethink the assumption that change in religion stemmed primarily from reaction to external pressures, I had to rethink the assumption that the separation of religion from politics was logical, desirable, and in any case an inevitable consequence of "modernization". In sum, I had to rethink what I had been taught. I had to unlearn in order to be 
able to learn anything valid and reliable about religion, society, and politics. Other theories and other methods had to be found.

As a first step, I had to free myself from dominant theories of modernization and secularization. I confess that I have never been much convinced by theories of modernization. They struck me as too neat, too linear, and I did not believe in its supposed inevitability. There was a lot of talk in the 1960s about "take off" to modernization, when we all know that take off is no guarantee of a smooth flight. Since that time, throughout my professional life I have preferred to work with more basic concepts-ideas, organizations, power, and conflict-and to see where they lead me. The concept of secularization was also of little help, at least in its most common and crude form, limited to the separation of institutions and the supposedly inevitable process of reducing religion to the private and personal, and to ultimate disappearance in the face of science and education. What I found instead was something more complicated and more interesting: a process of growing individual and group autonomy that came hand in hand with waves of creative innovation in religion.

The existing bibliography was of little or no help. At that time, the great majority of available work on these issues was by historians, for the most part working in a traditional vein. With rare exceptions, these works took a narrative approach, focused on church and state and the formal declarations or positions of leaders. The basic data were documents and legal accords, and the result was a narrowly institutional and formal approach. The criteria for selection of data (rarely stated explicitly) was whether or not something had to do with formal and legal church-state issues. ${ }^{2}$ The state of the art of the sociology of religion was also not of much help. At that time, much work remained excessively formal, and at least in the United States it was dominated by functionalist assumptions which made consensus a basic element for modernization. A good example was the work of Ivan Vallier (1970) Vallier had the virtue of going beyond documents and institutions and collecting systematic empirical data on the attitudes of contemporary Catholic leaders. His work was innovative and influenced a generation of students of the issues. The problem was that his basic thesis hinged on the need for consensus and withdrawal from politics in common pursuit of "development" at the very moment when pressures were rising on all sides to mobilize for political action, sometimes to pursue radical change, in others to support the existing order. Concepts of consensus turn out not to be of much help in times of conflict. ${ }^{3}$

As noted earlier, it was also necessary to rethink basic concepts of "religion" and "politics". Just as politics cannot be limited solely to governments or formal channels like elections or regulations, in the same measure, religion cannot be limited to the formal structures of the churches. It was and it remains a fatal error to identify religion and politics narrowly with "church and state". The formal institutions of church and states are of course important-they control resources and continue to command loyalties, although exactly how and in what measure remains an empirical question. But much more is at stake, and it was essential to find ways to open up the field of study, to look beyond the confines of both churches and states to ordinary behavior. We cannot be content with documents alone: most people don't read church documents. We need to examine how messages are transmitted and received, and how individuals and groups organize themselves to understand and act in and on the world.

In my experience, it is a mistake to assume that religion can be easily translated into a single, monolithic position in society and politics. There are always multiple positions, and who ends up speaking in the name of "religion" is a matter of contestation, and thus of power. It cannot be settled by definition. Indeed, if we locate the question of the political orientation of "religion" in a historical and comparative context, it becomes clear that religion is something like an empty vessel, a space that has been filled over the years with a wide range of positions, from the revolutionary tendencies of the English Puritans (who cut off the head of a king after a civil war) or of Camilo Torres or Chile's

\footnotetext{
For a recent example of this kind of work, see (Schwaller 2011).

Vallier did his field studies in Chile and was much influenced by the ideas of Christian Democracy, in power in that country from 1964 to 1970.
} 
Christians for Socialism to the conservative extreme of movements like Tradition, Family and Property and everywhere in between. The role of the African American churches in the Civil Rights movement (Branch 1986, 1998, 2006; Morris 1984; Harris 1999) is mirrored by the resurgent religious right in the U.S., now locked in a political embrace with Donald Trump: difficult to make sense of but a fact nonetheless.

In sum, my initial research in Colombia and Venezuela reality quickly showed me that it was necessary to study and understand the process from another angle. I wanted to get beyond leaders and documents, beyond what theologians or historians wrote. I wanted to know how ideas got to people, who carried them, in what form, and with what consequences for personal and collective behavior. My goal was to understand the process from within and to examine, in so far as possible, how actors themselves, elites and ordinary people, understood the process and organized themselves to act, with what goals, which values, what legitimating principles, and what organizational models.

In theoretical terms, I took the creation of meaning as a central focus, trying to grasp what actions and commitments meant to those involved. This means not to see them only in the light of my own preconceived questions (and then decide that they were ill-informed if they did not respond in the same terms) but rather to try to enter into the reality of others, using their words, their categories of analysis (Weber 1978b). It is not easy to do this, and many would say that it is impossible. But I believe that it is not necessary to become the other to nonetheless make progress in understanding the other making sense of the rules and values by which they live. Along with my interviews with bishops and formal organizations, I dug deep into current debates, I read theology for the first time, I interviewed pastoral agents of all kinds, I observed numerous community meetings, and I studied the history of organizations (Levine 1981).

In a subsequent work, a decade later, I turned the process upside down, working "from below" to understand the ordinary life of religious communities and then examine their connection to institutions. I did extensive field work with Christian base communities (in Spanish, comunidades eclesiales de base, or CEBS) in distinct regions and localities, once again in Colombia and Venezuela. I spent the better part of three years traveling in the cities and countryside of the two countries, in barrios and small villages, swallowing dust on rural buses. I went where I was told that no one ever went, I did interviews that I was told could not be done. I did life histories, I sat in on community meetings. I ended up with more than 3000 pages of interview transcript and field notes, which formed the basis of my Popular Voice in Latin American Catholicism (Levine 1992). This was research for someone young and robust as I was at the time, at least in relative terms. I would not be able to do it now.

For intellectual nourishment, I returned to an early interest in the sociology of knowledge, asking why, how, where, and under what conditions ideas arise and have an impact on behavior, an impact that lasts and consolidates. This kind of work requires entering fully into the context, not depending on data collected by others. This cannot be done by relying on an existing data bank: you have to be present, observe, and talk with people. ${ }^{4}$ So I began to educate myself, to learn the language of religion, and to understand how perceptions, judgments, and models of organization were formed. I tried to situate work, as Mills (1959) suggests, in the space between biography and history, with emphasis in the connections across levels. ${ }^{5}$ In the end, I did manage to unlearn much of what I had been taught, and to acquire new perspectives that I was able to put to use throughout my scholarly career.

I go into all this autobiographical detail to underscore once again the lesson of the Guatemalan preacher, the precursor I cited at the beginning of this paper. The lesson is that reality changes faster than theory, and that it is therefore essential to be open to surprises, to unexpected events and patterns that may not fit our preconceived scheme, to take them seriously and try to understand them, make

4 This is what American political scientist Key (1984) described as "soaking and poking".

5 (Mills 2000, p. 43) defines social science as "the study of biography, of history, of the problems of their intense interaction within social structure." 
sense of them within a theory which is ours to construct. All this brings me to a few obvious questions: have we made progress? Are we better off now than half a century ago?

\section{Are We Better off Now?}

The answer is yes, we are indeed much better off now, for a few very specific reasons. First, in the current state of the art as I understand it, an exclusive focus on formal structures and documents has been mostly left behind. These of course remain important, but a lot more now comes as part of the offering. We also have a wealth of studies now that recognize the need to examine "religion" in many forms and at multiple levels of experience. With a few notable exceptions, neither churches nor religious communities are taken as monolithic entities. ${ }^{6}$ Multiple tendencies and locations are recognized and multiple sites for conflict are identified within churches and communities. There is also now much systematic work that takes into account the impact of massive demographic and cultural transformations on religious change. When I first arrived in the region, the growth of literacy was becoming notable, along with a beginning edge of massive physical mobility, internal and international migration. Exploding access to mass communications and lately to the internet has amplified the impact of these social forces, opening masses of ordinary people to multiple sources of information (Parker 1996, 2005; Marzal 1988) and to the possibility of choice among multiple options. ${ }^{7}$

All this has an impact on the quality of affiliation in the church and on expectations of obedience. Membership and loyalty cannot be taken for granted, as some church leaders imagine was the case in some golden age of the past which they long to recreate. In all probability, the past was never so neatly ordered and structured as some imagine. Anyway, what seems to some to be a loss of order can be an opening of opportunities for others (Levine 2009; Romero 2009). In my own field work, I kept running into hollow shells of groups. Church officials would point them out on an organizational chart, but more often than not, there was little more than a name on a chart. No one could ever be found. ${ }^{8}$

These elements of the current state of the art mean that religious pluralism is now generally understood to be a central fact, something that provides both context and energies for cultural innovation and competition. Much contemporary work addresses the relation between the emergence of religious pluralism and the consolidation of democratic politics and more open civil societies in the region, following the resolution of civil wars and the end of military rule through the region in the 1980s (Hagopian 2009a; Levine 2009, 2012). The existence of a more open civil society, with lower barriers to organization, stimulates the creation of new groups, drawing in ambitious new generations of leaders and attracting members seeking an anchor, a community, in the new situations in which they find themselves.

The relation between the pluralization of religious options and the quality of open democratic politics is both simple and unexpectedly complicated. It is simple because the simple fact of having multiple actors and religious sites (churches, movements, communications media like radio or tv, publications, schools, or internet) creates more points of contact with politics than existed 50 years ago. One cannot now speak of "the Church" as if only one church had any public role: there are many. There is also something like a civil society within the churches (groups, movements, schools and universities, publications, radio stations) that has to be taken into account; social groups, publications, schools, and universities, all seeking voice and a legitimate place in public life (Romero 2009). The question gets more complicated as we enrich and broaden the meaning given to both "religion" and "politics".

6 Cf. much work in the rational choice vein, for example (Gill 1998). On the other hand, Chesnut (2003) and Chesnut (1997) work well with rational choice language to illuminate change centered on expanded sup-ply of religious alternatives an thus of expanded possibilities of choice by religious consumers who pro-vide members of new churches.

7 When I first worked in rural Colombia, I noted something like a funnel effect (ley del embudo in Spanish), whereby most information and choices were filtered through networks and agents of the church. There was no real competition. That situation has long been overcome.

8 It is therefore risky to refer to lists of church-related groups as "resources" for the hierarchy as they elab-orate plans. For an example of this, see (Hagopian 2009a, 2009b). 
Reality has now moved us well beyond the issues of "church and state" that dominated earlier research, well beyond traditional elites and what they write and say. There are more actors, new generations of leaders, potential members with greater access to information, greater possibilities of choice, and of alliances. These changes also open us to studying the dying relation among levels of action: individual and group; local, regional, national, and transnational. Any serious study needs to examine who these new leaders and followers are, where they come from, and how connections are made and sustained. In this context, movement and change arises from all parties to the process. Religious leaders and groups seek recognition and legitimation, they pursue resources and search for contact, access, and reliable allies. At the same time, political actors search for votes, building patron-client relations that can ensure steady support.

The political impact of these related transformations has often differed from what many anticipated. A central fact to note here is that evangelical and Pentecostal Protestantism has changed orientation. We are now well beyond traditional models of the new Protestantism (Lalive 2009; Willems 1967) that centered attention on a flight from the world in the effort to see one's should and create a community of the elect. A different vision now prevails, one that urges children of light to bring that light to the world. Living in a political world, new groups organize to understand, and evaluate on that world (Algranti 2011; López 2008).

The effect is often not what organizers expected. Numerous attempts to form evangelical parties, electoral alliances, or legislative blocs have on the whole met with little success-except perhaps in the case of Brazil. Leaders and followers with little political experience have entered naively into alliances where they have been more used than effective. ${ }^{9}$ Seeking recognition and legitimation, they have bonded with leaders as diverse as Venezuela's Hugo Chávez, Peru's Alberto Fujimori, with Brazil's new President, Jair Bolsonaro, and of course with Donald J. Trump himself, as with George W. Bush before him. So the experience is at best mixed, and calls to mind Max Weber's famous admonition in his 1919 essay on "Politics as Vocation". Weber warned against the danger of entering into politics in search of the salvation of one's soul, or of the soul of society. "The man who is concerned for the welfare of his soul and the salvation of the souls of others", he wrote, "does not seek these aims along the path of politics. Politics has quite different goals, which an only be achieved by force ... When the goal is pursued in accordance with the use of an ethos of intent in a war of faith, it can be damaged and discredited for generations to come" (Weber 1978a, p. 223). Tocqueville (1967) wrote something similar almost eighty years earlier in his observations on the kind of society he encountered in the United States in the 1840s. He was much taken with the religious vitality of the country, which differed so much from the ancient regime he had known in France. He ascribed the source of this vitality precisely to the distance between government and churches. When they are closely bound together, as in France, opposition to the first breeds opposition or indifference to the second. Religions thrive better on their own in the open market of an open society.

All this suggests that a prime challenge for new religious groups who seek role in the public sphere in Latin America today is to educate themselves in politics, to search for reliable allies (a scarce resource at the best of times) and direct their efforts at building communities, forming leaders, and elaborating projects that may be smaller in scope but perhaps with greater chance of success (Algranti 2011; López 1998, 2008). The recent experience of Latin America offers many examples of coalitions in which groups of religious inspiration or with some links to churches have doggedly and with some success pursued a range of goals: human rights, divorce or abortion, educational subsidies, local campaigns for housing or transport, work with gang members, migrants, or prisoners (Levine 2015b).

9 In general, religiously linked political parties have had little success. Once seen as a wave of the future, Christian Democracy has faded in most of Latin America. 


\section{Building a Future State of the Art}

What would a good agenda for future research look like? What should be included? Elsewhere (Levine 2015a) I discuss a number of elements that together might provide the backbone for a useful and productive future state of the art in the study of religion, society, and politics in Latin America. Each points to a set of issues that emerge from civil society. The churches and explicitly religious issue are involved and implicated, but less as initiators than as actors in a plural setting. This suggests beginning future work not from a specific concern with churches or "religion" but with the issues and contexts, and then seeing how churches and religion play a role. At a minimum, these include the following: 1 . sexuality, gender, and identity; 2 . spirituality and encounters with charismatic power; 3 . changing relations between religion and violence; 4 . new perspectives on secularization; 5. citizenship; 6 . ethnicity; 7 . ecology; 8 new generations of leaders and followers; 9 . communications and media. Limitations of time and space make it impossible for me to review all these elements here. I limit myself to three which illustrate well much of the realities of religion, society, and politics that are being transformed. These are: sexuality, gender and identity, spirituality and encounters with charismatic power, and violence.

The general area of sexuality, gender, and identity has changed rapidly in ways that make it a prime subject for research into religion, society, and politics. Change has been impelled by actors in civil society who have advanced their concerns and core issues in ways that implicate religion and the churches. The process has been highly contested with strong impact on personal lives and social conditions, with new models of what is legitimate and possible being advanced. When I began my own studies, this field was mostly concerned (at least in the public sphere) with issues of contraception and abortion, marriage and divorce, and family legislation. The long-standing concept of patria potestad, which affirms the authority of men in household and property, was still mostly unchallenged (Htun 2003, 2009). When I first arrived in Colombia, I was so naive that I asked a friend if there was civil divorce in the country. The response was "Civil divorce? We don't even have civil marriage here" To get a civil marriage, the parties had to make a public declaration of apostasy, of loss of faith and abandonment of membership in the church. This was a strong social disincentive and many went out of the country to marry. ${ }^{10}$

Older problems of sexuality and gender like contraception and abortion persist, but now they must share the public sphere with other, highly contested issues such as gender rights, gay rights, same-sex marriage (known in Spanish as egalitarian marriage, or matrimonio igualitario) and of course now with the avalanche of cases of clerical sex abuse and cover-up by high church officials (e.g., Goodstein 2018). In his many visits to the region, Pope Francis has led the way in bringing public attention and support to those involved in issues like migration, ecology, and inequality (Levine 2016b). But on matters of sexuality and gender, and in particular on the need for transparency and accountability in cases of clerical sexual abuse, he has made numerous missteps. Within Latin America, the case of Chile has been particularly visible, with arrests, police raids on church archives, and the resignation of all the bishops of the Catholic Church. Pope Francis has played a contradictory role. In a disastrous visit at the beginning of 2018, he chided accusers of priests and bishops for "calumny", only later to recant, apologize, and demand resignations and investigations. One element that is notable in this case as in others, from the U.S. to Ireland, Germany to Australia, is that the Catholic Church has lost its air of untouchability. ${ }^{11}$ Politicians and police who long turned a blind eye find it hard to do so now. Police

10 This is similar to the situation in Israel today, where the official rabbinical establishment oversees any marriages. Many secular Israelis make the short trip to Cyprus for a civil marriage.

11 In a recent editorial (National Catholic Reporter 2018), the National Catholic Reporter stated that “... there has been a kind of 'paradigm shift' in how Catholics view the scandals. It once was perceived as the crimes of a small and disturbed group of clerics, but it became clear that the problem was widespread, not only in this country but throughout the globe with a similar narrative from country to country. As a result, Catholics began seeing it as a systematic problem of tolerated and accepted crime. And if that were the case, then a great many presumptions about who we are as Catholic and what the church and the clergy mean are called into question." 
raid church archives, priests and bishops are indicted and arrestees: behaviors unthinkable fifty years ago (Goodstein 2018; Robertson 2018). To be sure, the nineteenth century was filled with church-state conflicts, often involving violence and clerical expulsions, but those disputes were centered around classic issues of control over property and education. The dynamics of the current disputes centered on sexuality, and clerical abuse are different. The process, the actors, and of course the context differ sharply from the past. This is a new world.

This is clearly a process that has been building for a long time, impelled by groups from civil society, above all groups of victims along with associations of lawyers, doctors, and social workers and human rights groups. They have fought to make these issues central to the public agenda. The question for analysis is to understand why now, and why in this way. Why has it been possible now to break through the cover of silence and indifference and demand accountability? The question is why has it been possible here and now to win access to the public sphere. To find an answer requires tracing the history of these groups and understanding how networks were built and sustained. Any study will have to work in many sites and with a great variety of data including analysis of social movements, of legal proceedings of legislation, combined with attention to the public discourse of churches and political leaders, and the transnational connections of movements.

Under the heading of spirituality and encounters with charismatic power, there are two points to bear in mind. First, the great surge of creative innovation and growth in religion in Latin America is highly influenced by Pentecostal beliefs and practices (Chesnut 2003, 1997; Steigenga 2001; López 2008; Algranti 2011). This is not limited to Protestant churches new or old. The Catholic Charismatic Renewal is itself one of the fastest growing movements in the entire region (Steigenga and Cleary 2007; Cleary 2011). The specific variants of Pentecostal experience run from intense personal and collective prayer, belief in divine healing, and public exorcisms (often televised), visions and speaking in tongues (glossalalia) to brief in a health and wealth gospel according to which true believers will be showered with material goods. ${ }^{12}$ In all its variants, Pentecostalism provides believers with an intense personal and collective experience of contact with the divine.

The new centrality of Pentecostal practice is a prime example of multiple and simultaneous creation. There was no single point of origin. Instead, initiatives popped up all across the region eventually making contact and consolidating. Contacts and news somehow flowed across borders and filtered down through social levels. I still recall one instance when I was working with a neighborhood group, a Christian base community in the city of Cali Colombia. They knew that I was an American and soon asked me for ways to contact the Word of God Movement. Word of God is an acknowledged source for the Catholic Charismatic Renewal in U.S. Catholicism. How they knew about the movement was a mystery to me. This was all well before massive access to the internet or even to reliable mail or telephones. But somehow information makes it through.

Studying phenomena of intense spirituality and encounters with charismatic power can be a challenge for many social scientists who are made uncomfortable by phenomena they cannot easily touch or measure with standard approaches. Most have been trained to remain neutral, to keep a distance, to avoid "going native". There can also be personal or psychological problems in accepting the reality of this kind of encounter. But to understand the social power of what is happening in churches across the region, it may be necessary to take the risk of crossing that line that separates the observer from the actor, the believer from the student (Harding 1987). The first step is to take these experiences seriously: not as some aberrant phenomenon, but rather as a key element of personal and collective experience, not to explain it away but to try to get inside and understand it as much as possible. It will not be easy. I know lots of sociologists who can talk all day about religion in the abstract but who turn their eyes away in front of a Santeria altar, and who have nothing to say in the presence of a public exorcism where thousands of people are chanting "out with the Devil"!!! I still

12 See (Gifford 2004), for fascinating detail on the prosperity gospel and new churches in Ghana. 
recall the shock I gave to some colleagues when I told them that if my interviewees said that they had had a vision, well then, they had a vision. We need to work with it. Or as they say in Colombia, "no creo en brujas, pero que vuelan, vuelan ("I don't believe in witches, but if they fly, well then, they fly").

To work with phenomena of this kind it is essential to be present, to be on the scene, to observe, to listen, to interview, to work with videos (often easily available) and occasional pamphlets which members are usually delighted to share. The power of these experiences is not limited to words, so it is also important to listen to music, to examine iconography to observe the emotional tone of meetings, and to look at the objects people touch and use. Because many of the most successful Pentecostal and neo-Pentecostal churches are new, it is of particular interest to understand how they were set up and how they grew, who the leaders are, what members are taught and how new leaders are trained, how the churches are structured, and what leadership styles are like. There is already good work on these issue (Algranti 2011; Fonseca 2008; Freston 2001; Kramer 2005; Oro and Saman 2000) and more is needed.

Elsewhere I have written extensively on the changing relations between religion and violence in Latin America (Levine 2011, 2012, 2016a). So I will be brief here. Any discussion of violence benefits by being concrete and specific. My concern here is above all with coercive violence: the violence that forces itself on people, that wounds, tortures, and kills, that leaves widows and orphans, along with complex and lasting psychological, social, and economic suffering. With the end of military rule and the resolution of civil wars across the region, the character and social location of violence has shifted. Massive state repression and open civil war have happily passed from the scene, but of course violence remains and in some cases takes an even greater toll (Wilde 2015). Any current portrait of violence in Latin America must take account of new forms of violence including the impact of drugs and gangs, the violence that accompanies internal and transnational migration (Frank-Vitale 2015), the ordinary violence of mostly unaccountable police and so-called security forces, (Brinks 2010) violence in the truly horrific prison systems (Johnson 2015), and of course the continuing presence of domestic and child abuse.

The transformation of violence and its more multiple and decentralized manifestations has been matched by the transformation of religion into a multiple and decentralized field. In the most recent era of military rule, religious leaders often led the resistance to state oppression most notably in cases like Chile, Brazil, or El Salvador, mobilizing option and providing support and resources to victims. ${ }^{13}$ The Catholic church dominated the scene. But now any action by the Catholic Church is matched and often exceeded by multiple actions undertaken by multiple churches and religiously inspired groups of all kinds Three good examples are work with gangs and gang members (Brenneman 2012, 2015), work in jails and prisons, and assistance to those faced with coercion, robbery, rape, and abuse as they attempt to migrate.

The phenomenon of gangs fueled by drug wars is present everywhere but most studied in Central America and Brazil. (Brenneman 2012, 2015; Insight Crime 2015) references cited in (Levine 2010, 2012, 2016a). Alongside the conventional Catholic repertoire of official chaplains or truce negotiations brokered by bishops, a range of options have emerged from the new churches including direct work with gangs and gang members. Many gangs are notorious for punishing any effort to leave with killing, but exceptions are commonly made for those who claim to have found Jesus. Real believers are given a pass out although the gang checks up to make sure that conversion is lasting. For their part, churches welcome new members, provide tattoo removal clinics ${ }^{14}$ and access to work in a supportive community. In some prisons, evangelicals pastors have entered and managed to create "evangelical blocs", areas in which inmates withdraw from gang rule to live a gospel life, governing themselves

13 Catholic leaders were rarely united on these issues and in some cases the bulk of the hierarchy was solid-ly in support of military rule, Argentina is a prime example.

14 The extensive tattooing of gang members (often including the entire face) can be a frightening sight, and thus presents a bar to social reintegration. Removal is painful and difficult but it can help. 
with the help of the churches. In the case of migrants, for example from Central America to the "Norte", the role of churches of all kinds (Catholic and evangelical) has been notable long before Donald Trump made migration his core issue. Pope Francis gave an impassioned homily in a mass at the U.S.-Mexico border, remembering migrants who died in the effort to reach the border (Levine 2016b). On their way north, many hitch notoriously dangerous rides on the train (known as la bestia, the beast) where they are regularly victims of robbery, rape, and often murder. The little help that is offered (food, water, shelter for the night, medical assistance) comes from scattered initiatives by churches or local religious groups (Levine 2016a; Frank-Vitale 2015).

In all the areas mentioned here (sexuality, gender and identity, spirituality and encounters with charismatic power, and violence) action arises from numerous scattered local and regional groups, sometimes specifically religious, sometimes not. The implication for research is that future students of the matter would do well to begin not by studying churches but rather by identifying sites of conflict and contestation, and then look to ways in which religion may be involved.

\section{Reflections on Theory and Method}

A central thread in any effort to draw a history of the state of the art is the need to locate any specific study in a historical and structural context in ways that can shed light on how individual and collective experience are bound together. This is what Mills meant by focusing on the intersection of biography and history. Structuring work in this way allows us to concentrate on lived experience, to understand how meaning is formed and acted upon, not in isolation but in some structured relation to other social levels. After all, religious experience itself is necessarily both personal and collective, both private and public. Analysis has to recognize and value that complexity. There is a concrete social process in which people, material resources, ideas, and models of organization travel back and forth, linking the local and personal with larger networks and formal structures. In my own work, I have traced these connections in multiple ways: tracking the social history of a pamphlet or an audio cassette, asking who produced them and how they got to their destination. It makes a difference who brings ideas to groups and communities and so I have also studied the careers of pastoral agents, and the history of group membership. All these processes are more complicated and multiple than they were half a century ago, but in the same measure they are also richer and more interesting.

The question that preoccupies me here is what can we do to ensure that any future state of the art will yield better studies, more valid and reliable data, more insights into patterns and dynamics of change. The task is at once theoretical and methodological. In theoretical terms, efforts at building grand theories to order and explain everything are likely to be less useful than work with mid-range theory that can generate concepts able to specify elements of a complex and multileveled reality, that can identify likely sites for innovation and conflict, point to channels of access, and leave substantial room for questions of meaning. If we do not understand what motivates people, what seems to them to be legitimate and possible and why they find it in what we call "religion", it will be difficult to grasp the source and rhythm of change, and to understand where it may lead in the future.

To explain something, it is necessary to locate the general in the specific and particular, to construct a relation between otherwise isolated cases, and to show how and why they fit together in relations that can then be extended to other levels. Having a clear theoretical focus is what allows us to take any study beyond simply accumulating instances of some phenomenon, naming them, and sorting them into categories. Collecting data and building typologies should always be subordinate to explanation. Without a theory, typologies lead to no conclusions of particular interest. This reflection brings me to a final autobiographical note.

In the mid-1960s, I received a Master's degree in Political Sociology from the London School of Economics. During my time in London, I was privileged to attend lectures on the philosophy of science by Karl Popper. Popper began one session this way: "Gentlemen, observe". There was stunned silence in the auditorium: none of us knew what to say or do. Popper then drove home the point. "You see", he said, "to observe you need a theory." Popper elaborated further: without a theory, it is 
impossible to know what to observe, how to isolate any specific element from the swirl of a complex and always-changing reality. Without a theory, it is impossible to know what may constitute a unit of analysis or how individual units may fit together into some organized whole.

The theories that can open us to a better state of the art will be those that can provide us with tools to identify the origins and dynamics of socioreligious phenomena, give us an explanation of its power to convince, and to organize behavior. They should also be able to identify the new social forces and creative energies that carry it forward, and to recognize when they are successful and also when they fail, because many do fail. So we need theory, theory that makes a central place for continuous change, theory that will shed light on the relations between religion and politics, and for Latin America specifically, between religious pluralism and political alternatives, not to trace lines of separation, but rather in search of synthesis and mutual influence.

In terms of method, I limit myself to noting a few essential points. In the design of any study, it is important to build in a comparative dimension, with work in varied sites and social levels. Even if the data are based exclusively on field work within Latin America, or within any particular country, the available bibliography can enrich any study with comparative references. In my experience, it is useful to work with mixed methods, combining quantitative with qualitative data (large and small surveys, depth interviews, observation, collections of documents and pamphlets, iconography and music, web sites and videos). A mixed approach yields a denser and richer portrait of reality than can be derived from any single data source. The problem for many scholars today is that work of this kind is difficult, time-consuming, and on occasion dangerous. Considerations of career make people want to publish more quickly, and with what they imagine to be "hard data." It is simpler to access a data bank.

But I believe strongly that going into the field, observing, touching, talking, and listening make possible a much richer and more complete understanding of reality and what it means to the actors themselves. It opens us to grasping more fully how actors see and value the world and how they organize themselves to act within it. It helps us understand what it means to say that ideas shape reality. In Latin America today, religious actors of all persuasions work every day to create and sustain communities, to give meaning to personal and collective life, and to have an impact on the public sphere. Contrary to what classic theories of modernization and secularization led us to expect, they do not fade gently into private life, but rather find new and often surprising ways to enter to understand the world, and act within it. This is where the work is for future generations.

Funding: This research received no external funding.

Conflicts of Interest: The author declares no conflict of interest.

\section{References}

Algranti, Joaquin. 2011. Política y Religión en las Márgenes. Nuevas Formas de Participación Social de las Mega Iglesias Evangélicas en la Argentina. Buenos Aires: Ediciones Ciccus.

Branch, Taylor. 1986. Parting the Waters. America in the King Years, 1953-1963. New York: Simon and Schuster.

Branch, Taylor. 1998. Pillar of Fire. America in the King Years, 1963-1965. New York: Simon and Schuster.

Branch, Taylor. 2006. At Canaan's Edge. America in the King Years, 1965-1968. New York: Simon and Schuster.

Brenneman, Robert. 2012. Homies and Hermanos. God and Gangs in Central America. Oxford: Oxford University Press.

Brenneman, Robert. 2015. Violence, Religion and Institutional Legitimacy in Northern Central America. In Religious Responses to Violence: Human Rights in Latin America Past and Present. Edited by Alexander Wilde. Notre Dame: University of Notre Dame Press, pp. 371-95.

Brinks, Daniel. 2010. Violencia de Estado a Treinta Años de Democracia en America Latina. Journal of Democracy en Español 2: 10-27.

Chesnut, R. Andrew. 1997. Born Again in Brazil. The Pentecostal Boom and the Pathogens of Poverty. New Brunswick: Rutgers University Press.

Chesnut, R. Andrew. 2003. Competitive Spirits. Latin America's New Religious Economy. Oxford: Oxford University Press. Cleary, Edward. 2011. The Rise of Charismatic Catholicism in Latin America. Gainesville: University of Florida Press. 
Cox, Harvey. 1995. Fire from Heaven The Rise of Pentecostal Spirituality and The Reshaping of Religion in the Twenty-First Century. Boston: Addison Wesley.

Fonseca, Alejandro. 2008. Religion and Democracy in Brazil: A Study of the Leading Evangelical Politicians, 1998-2001. In Evangelical Christianity and Democracy in Latin America. Edited by Paul Freston. Oxford: Oxford University Press, pp. 163, 206.

Freston, Paul. 2001. Evangelicals and Politics in Asia, Africa and Latin America. Cambridge: Cambridge University Press. Frank-Vitale, Amelia. 2015. Fui migrante y me hospedaron, The Catholic Church's Response to Violence against Central American Migrant in Mexico. In Religious Responses to Violence: Human Rights in Latin America Past and Present. Edited by Alexander Wilde. Notre Dame: University of Notre Dame Press, pp. 417-43.

Gifford, Paul. 2004. Ghana's New Christianity: Pentecostalism in a Globalising African Economy. Bloomington: Indiana University Press.

Gill, Anthony. 1998. Rendering Unto Caesar. The Catholic Church and the State in Latin America. Chicago: University of Chicago Press.

Goodstein, Laurie. 2018. Investigators Raid offices of President of U.S. Catholic Bishops. The New York Times, November 28.

Gutierrez, Gustavo. 1971. Teología de la Liberación Perspectivas. Lima: CEP. First published in English as A Theology of Liberation Maryknoll, Orbis 1973.

Harris, Frederick C. 1999. Something within. Religion in African American Political Activism. Oxford: Oxford University Press.

Hagopian, Frances. 2009a. Introduction: The New Landscape. In Religious Pluralism, Democracy and the Catholic Church in Latin America. Edited by Frances Hagopian. Notre Dame: University of Notre Dame Press, pp. 1-66.

Hagopian, Frances. 2009b. The Catholic Church in a Plural Latin America: Toward a New Research Agenda. In Religious Pluralism, Democracy and the Catholic Church in Latin America. Edited by Frances Hagopian. Notre Dame: University of Notre Dame Press, pp. 429-66.

Harding, Susan. 1987. Convicted by the Holy Spirit. The Rhetoric of Fundamental Baptist Conversion. American Ethnologist 14: 167-81. [CrossRef]

Htun, Mala. 2003. Sex and the State: Abortion, Divorce, and the Family under Latin American Dictatorships and Democracies. Cambridge: Cambridge University Press.

Htun, Mala. 2009. Life, Liberty, and Family Values: Church and State in the Struggle over Latin America's Social Agenda. In Religious Pluralism, Democracy, and the Catholic Church in Latin America. Edited by Frances Hagopian. Notre Dame: University of Notre Dame Press, pp. 335-64.

Insight Crime. 2015. Special Report: Gangs in Honduras. Available online: https://www.insightcrime.org/ investigations / special-report-gangs-in-honduras/ (accessed on 9 December 2015).

Johnson, Andrew. 2015. The Politics of Presence: Evangelical Ministry in Brazilian Prisons. In Religious to Violence. Human Rights in Latin America Past and Present. Edited by Alexander Wilde. Notre Dame: University of Notre Dame Press, pp. 395-416.

Key, Vladimir Orlando. 1984. Southern Politics in State and Nation. Knoxville: University of Tennessee Press.

Kramer, Eric. 2005. Spectacle and the Staging of Power in Brazilian Neo Pentecostalism. Latin American Perspectives 32: 95-120. [CrossRef]

Lalive, D’Epinay. 2009. El Refugio de las Masas Estudio Sociológico del Protestantismo Chileno. Santiago: Universidad de Santiago de Chile.

Levine, Daniel H. 1981. Religion and Politics in Latin America. The Catholic Church in Venezuela and Colombia. Princeton: Princeton University Press.

Levine, Daniel H. 1992. Popular Voices in Latin American Catholicism. Princeton: Princeton University Press (In Spanish as Voces Populares en el Catolicismo Latinoamericano Lima CEP 1996).

Levine, Daniel H. 2009. Pluralism and Challenge and Opportunity. In Religious Pluralism, Democracy and the Catholic Church in Latin America. Edited by Frances Hagopian. Notre Dame: University of Notre Dame Press, pp. 405-28.

Levine, Daniel H. 2010. Reflections on the Mutual Impact of Violence and Religious Change in Latin America. Latin American Politics and Society 52: 131-50. [CrossRef]

Levine, Daniel H. 2011. Camilo Torres: Fe, Política, y Violencia. Sociedad y Religión 21: 59-91.

Levine, Daniel H. 2012. Politics Religion and Society in Latin America. Boulder: Lynne Rienner. 
Levine, Daniel H. 2015a. Constructing an Agenda for Future Research on Religion in Latin America. Issues and Methods. Paper presented at the Meetings of the Latin American Studies Association, San Juan, Puerto Rico, May 28.

Levine, Daniel H. 2015b. The Evolution of the theory and Practice of Rights in Latin: American Catholicism. In Religious Responses to Violence, Human Rights in Latin America. Edited by Alexander Wilde. Notre Dame: University of Notre Dame Press, pp. 27-61.

Levine, Daniel H. 2016a. Real Violence and Real Religion. In Anuario de Historia de América Latina (Jahrbuch fur Geschichte Lateinamerikas). Wien/ /Koln/Weimar: Blau Verlag, pp. 237-48.

Levine, Daniel H. 2016b. What Pope Francis Brings to Latin America. CLALS Working Paper No 11. Washington, DC: American University Center for Latin American and Latino Studies. Available online: http:/ / papers.ssrn. com/sol3/papers.cfm?abstract_id=2761467 (accessed on 12 April 2016).

López, Darío. 1998. Los Evangélicos y los Derechos Humanos. La Experiencia del Concilio Naconal Evangélico del Peru. Lima: Ediciones Puma.

López, Darío. 2008. El Nuevo Rostro del Pentecostalismo Latinoamericano. Lima: Ediciones Puma.

Marzal, Manuel. 1988. Los Caminos Religiosos de los Migrantes a la Gran Lima: El Caso de el Augustino. Lima: Fondo Editorial, Pontificia Universidad Católica del Peru.

Mills, C. Wright. 1959. The Sociological Imagination. Oxford: Oxford University Press.

Mills, C. Wright. 2000. The Sociological Imagination. Fortieth Anniversary Edition. Oxford: Oxford University Press.

Morris, Aldon D. 1984. The Origins of the Civil Rights Movement. Black Communities Organizing for Change. New York: The Free Press.

National Catholic Reporter. 2018. Bishops have yet to find collective moral core. National Catholic Reporter, November 30-December 13, p. 20.

Oro, Pedro Ani, and Pablo Saman. 2000. Pentecostalism in the Southern Cone Countries: Overview and Perspective. International Sociology 15: 605-27. [CrossRef]

Parker, Cristián. 1996. Popular Religion and Modernization in Latin America. Ossining: Orbis.

Parker, Cristián. 2005. America Latina.¿Ya no es Católica? Cambios Culturales, Transformaciones del Campo Religioso y Debilitamiento de la Iglesia. America Latina Hoy Revista de Ciencias Sociales 41: 35-56.

Robertson, Campbell. 2018. Lists of Priests Accused of Sex Abuse are Pleased across U.S. The New York Times, December 15.

Romero, Catalina. 2009. Religion and Public Spaces. Catholicism and Civil Society in Peru. In Religious Pluralism, Democracy and the Catholic Church in Latin America. Edited by Frances Hagopian. Notre Dame: Press University of Notre Dame Press, pp. 365-401.

Schwaller, John F. 2011. The History of the Catholic Church in Latin America: From Conquest to Revolution and beyond. New York: Oxford University Press.

Steigenga, Timothy. 2001. The Politics of the Spirit. The Political Implications of Pentecostalized Religion in Costa Rica and Guatemala. Lanham: Lexington Books.

Steigenga, Timothy, and Edward Cleary, eds. 2007. Conversion of a Continent. Contemporary Religious Change in Latin America. New Brunswick: Rutgers University Press.

Stoll, David. 1990. Is Latin America Turning Protestant? Berkeley: University of California Press.

Tocqueville, Alexis. 1967. Democracy in America. New York: Harper and Row, vol. 1.

Vallier, Ivan. 1970. Catholicism, Social Control, and Modernization in Latin America. Englewood Cliffs: Prentice-Hall. Weber, Max. 1978a. Politics as a Vocation. In Max Weber Selections in Translation. Edited by W. Garry Runciman. Cambridge: Cambridge UP, pp. 212-25.

Weber, Max. 1978b. The Concept of Following a Rule. In Max Weber Selections in Translation. Edited by W. Garry Runciman. Cambridge: Cambridge University Press, pp. 99-110.

Wilde, Alexander, ed. 2015. Religious Responses to Violence. Human Right in Latin America. Notre Dame: University of Notre Dame Press.

Willems, Emilio. 1967. Followers of the New Faith Culture Change and the Rise of Protestantism in Brazil and Chile. Knoxville: University of Tennessee Press.

(C) 2019 by the author. Licensee MDPI, Basel, Switzerland. This article is an open access article distributed under the terms and conditions of the Creative Commons Attribution (CC BY) license (http:/ / creativecommons.org/licenses/by/4.0/). 